\title{
The Right to Jury Trial Under Title VII of the Civil Rights Act of 1964
}

Title VII of the Civil Rights Act of $1964^{1}$ is a legislative attempt to deal with the problem of employment discrimination based on race, color, religion, sex, or national origin. Although the general purpose of the legislation is clear, a number of procedural questions which are potentially vital to the achievement of that purpose were not explicitly resolved by the statute. ${ }^{2}$ One of these questions is whether a right to jury trial exists under Title VII. The importance of that question is revealed by the context in which it has arisen. Almost without exception, three facts are common to the discoverable ${ }^{3}$ Title VII cases in which a jury was requested: (1) the request was made by the defendant; (2) the suit was brought in the South; (3) the plaintiff alleged that the discrimination was racially motivated. ${ }^{4}$

These facts suggest that some southern defendants hope to utilize sympathetic juries to avoid the imposition of the sanctions provided in Title VII for racial discrimination-the underlying assumption being that white jurors, who may themselves be competing with blacks for jobs, will be less sympathetic than a federal judge to the discrimination claims of the black workers. ${ }^{5}$ In this country, however, the right to jury trial is cherished as a fundamental constitutional guarantee. Even considerations of social justice reflected in congressional legislation will not justify abridgment of such a constitutionally protected right. ${ }^{6}$ Thus in determining whether there is a right to jury trial in

142 U.S.C. \$ $2000 \mathrm{e}$ to $\$ 2000 \mathrm{e}-15$ (1964).

2 For example, see the discussion of the validity of the Equal Employment Opportunities Commission state deferral procedures in Comment, $A$ Look at Love v. Pullman, 37 U. CHI. L. REv. 181 (1969).

3 The Title VII cases involving the jury trial issue cited in this comment include the reported cases and those unreported cases noted in EEOC, Summary of Federal Court Decisions Involving Fair Employment Practices under Federal Law, April 15, 1969.

4 In the ten Title VII jury cases cited below, there is a single exception. In Cheatwood v. South Central Bell Telephone \& Telegraph Co., 59 CCH Lab. Cas. I 9214 (M.D. Ala. 1969), the plaintiff alleged sex discrimination.

5 See Note, Jones v. Mayer: The Thirteenth Amendment and the Federal Anti-Discrimination Laws, 69 Colum. L. REv. 1019, 1051 \& n.229 (1969).

- This conflict of values has been examined in relation to the right to jury trial in criminal contempt proceedings against those accused of violating federal court desegregation orders. Goldfarb and Kurzman, Civil Rights v. Civil Liberties: The Jury Trial Issue, 12 U.C.L.A.L. REv. 486 (1965). 
Title VII cases, courts must look not only to the language and intent of the legislation, but also to the limitations which the Constitution imposes upon the legislators.

The clear majority of district courts which have ruled on the issue have denied requests for jury trials in Title VII cases. In Culpepper $v$. Reynolds Metals Co., ${ }^{7}$ after a lengthy consideration of this "vexsome problem,"8 the court concluded that there was no statutory or constitutional right to jury trial in Title VII cases. The Culpepper court listed the handful of other cases in which district courts were faced with the issue, noting that only in Hayes v. Seaboard Coast Line Railroad $^{9}$ had any genuine study been given to the subject. ${ }^{10}$ The Hayes court looked to the language of Title VII and concluded that jury trial would "thwart the will of Congress and to an extent frustrate the purposes of the legislation." 11 In Cheatwood v. South Central Bell Telephone of Telegraph Co., 12 the court denied defendant's demand for jury trial primarily on the basis of the Hayes decision, and in Anthony v. Brooks ${ }^{13}$ jury trial was refused because the suit was viewed as one solely for injunctive relief. The Culpepper decision was approved and followed in Long $v$. Georgia Kraft Co. ${ }^{14}$ Requests for jury trial were struck without discussion in Lea $v$. Cone Mills, ${ }^{15}$ Banks $v$. Local 136, IBEW, ${ }^{16}$ and Witherspoon v. Mercury Freight Lines, Inc. ${ }^{17}$ But in Johnson v. Georgia Highway Express, Inc., ${ }^{18}$ the district court denied plaintiff's motion to strike defendant's demand for a jury trial on constitutional grounds. And in Allen v. Braswell Motor Freight Lines, Inc., ${ }^{19}$ a Title VII suit was tried to a jury. ${ }^{20}$ It is not clear whether a motion to strike the demand for a jury trial was made in that case.

With the exception of Culpepper and Hayes, the district court opin-

7296 F. Supp. 1232 (N.D. Ga. 1969) (pending appeal).

$8 I d$. at 1239.

846 F.R.D. 49 (S.D. Ga. 1969).

10 Culpepper v. Reynolds Metals Co., 296 F. Supp. 1232, 1240 (N.D. Ga. 1969).

1146 F.R.D. 49,53 (S.D. Ga. 1969).

1259 CCH Lab. Cas. I 9214 (M.D. Ala. 1969).

$1356 \mathrm{CCH}$ Lab. Cas. T 9090 (N.D. Ga. 1967).

1460 CCH Lab. Cas. 9237 (N.D. Ga. 1969).

15 C.A. No. C-176-D-66 (M.D.N.C. 1968) (unreported).

16 G.A. No. 67-598 (N.D. Ala. 1968) (separate order denying jury trial, Jan. 25, 1968) (unreported).

1759 CCH Lab Cas. I 9219 (S.D. Ala. 1968).

1847 F.R.D. 327 (N.D. Ga. 1968).

19 G.A. No. 3-2112-14 (N.D. Tex. 1968) (unreported).

20 Other Title VII claims have undoubtedly been tried to juries but were not reported or noted in the EEOC case summary pamphlets. See note 3 supra. The number of these cases is probably small, but no estimate can be confidently made. 
ions do not provide much assistance in dealing with the problems raised by the jury trial issue. The district courts appear to have been awaiting guidance from the higher federal courts. ${ }^{21}$ The issue finally reached the Court of Appeals for the Fifth Circuit in Johnson v. Georgia Highway Express, Inc. ${ }^{22}$ The Fifth Circuit reversed the district court and held that a request for back pay under Title VII did not provide the defendant with a right to jury trial. Unfortunately, the court supplied only a brief justification of its decision. In view of the importance of the issue to the enforcement of Title VII and of the difficult constitutional problems which are involved, a more complete judicial investigation of the issue is needed to provide a definitive resolution to the jury trial question under Title VII.

In examining the right to jury trial under Title VII, this comment will consider the two questions which the courts must resolve: (1) whether Congress intended that Title VII suits be tried to juries, and (2) irrespective of congressional intent, whether the seventh amendment guarantees the right to jury trial in Title VII cases.

\section{STATUTORY INTENT}

The courts have looked first to the language and history of Title VII to see if the legislation itself provides a right to jury trial. There is no specific provision in the Act on the subject of jury trial in civil suits brought under Title VII. But the Act does contain language which seems to indicate that a jury trial was not contemplated by Congress. The following enforcement provision sets out the forms of relief which may be granted upon a finding of unlawful discrimination:

If the court finds that the respondent has intentionally engaged in or is intentionally engaging in an unlawful employment practice charged in the complaint, the court may enjoin the respondent from engaging in such unlawful employment practice, and order such affirmative action as may be appropriate, which may include reinstatement or hiring of employees, with or without back pay . . . ${ }^{23}$

Nowhere, so far, has it been argued seriously that Congress intended to provide for jury trials when the relief sought and granted is solely

21 On January 14, 1969 the Hayes court issued a supplemental order denying a motion for interlocutory appeal of the jury trial issue. Explaining its decision, the court remarked: "I am confident that by the time we get down to a hearing on the merits in this case the jury issue feature under Title VII will have been authoritatively dealt with on higher levels." Hayes v. Seaboard Coast Line R.R. Co., 46 F.R.D. 49, 56 (S.D. Ga. 1969).

22 Johnson v. Georgia Highway Express, Inc., No. 26974 (5th Cir., Oct. 30, 1969).

2342 U.S.C. \& $2000 \mathrm{e}-5(\mathrm{~g})(1964)$. 
injunctive. The demands for jury trial have been made by defendants when plaintiffs are seeking a back pay award. The language that "the court" may order any affirmative action including awarding of back pay in addition to injunctive relief would suggest that the statute contemplates that the judge without a jury will determine all appropriate relief in a single order. ${ }^{24}$

This interpretation of the enforcement provision is supported by the similarity of the provision's language to the language of section 10(c) of the National Labor Relations Act, ${ }^{25}$ which Congress knew afforded no jury trial right:

... and to take such affirmative action, including reinstatement of employees with or without back pay ... .6

Moreover, the fact that Congress has specifically provided the right to jury trial in cases of criminal contempt under Title VII, ${ }^{27}$ and in civil suits under other legislation, ${ }^{28}$ suggests that if Congress intended to provide a jury trial right in civil suits under Title VII, it would have done so specifically.

The legislative history of Title VII offers another possible source of guidance in determining the statutory intent. Although the legislative history of Title VII is somewhat irregular, ${ }^{29}$ certain comments during the floor debates indicate that neither the supporters nor the opponents of Title VII envisioned jury trials in the ordinary civil proceedings.

24 See, e.g., Culpepper v. Reynolds Metals Co., 296 F. Supp. 1232, 1239 (N.D. Ga. 1969).

25 The comparison with the NLRA is supported by the legislative history of Title VII as well as by the similarity of the language. In the original House version of H.R. 7152 an "Equal Employment Opportunity Board" was established and provided with powers similar to those of the NLRB. The Senate eliminated the Board but retained the enforcement language which had provided that the Board could "... take such affirmative action including reinstatement or hiring of employees, with or without back pay. . . " H.R. $7152 \S 709(\mathrm{i})$ in its original version reported in Hearings Before Subcomm. No. 5 of the House Comm. on the Judiciary, 88th Cong., Ist Sess., ser. 4, pt. 3, at 2294 (1963).

26 These words appeared in the National Labor Relations Act, 49 Stat. 449, § 10(c) (1935) and were later incorporated into the Labor-Management Relations Act, 29 U.S.C. § 160(c) (1964). In NLRB v. Jones \& Laughlin Steel Corp., 301 U.S. 1, $48-49$ (1937), the Supreme Court rejected the contention that back pay orders under $\$ 10$ (c) afforded a right to jury trial.

2742 U.S.C. $\$ 2000(\mathrm{~h})(1964)$.

28 See, e.g., 28 U.S.G. $\$ 2402$ (1964) (civil actions against United States to recover taxes); 46 U.S.C. $\S 688$ (1964) (actions by seamen for injury or death under Jones Act); 28 U.S.C. § 959(a) (1964) (suits against federal trustees, receivers, or managers). See generally 5 MOORE's Federal PRACTice I 38.12 (2d ed. 1968).

29 For the most complete judicial examination of the statutory language and history in relation to the jury trial issue, see Culpepper v. Reynolds Metals Co., $296 \mathrm{~F}$. Supp. $1232,1239-40$ \& n.5 (N.D. Ga. 1969). See generally EEOC, LegisLattve HustoRy of TITLES VII AND XI of CIVIL RIGHTS AGT of 1964 (1968); Vaas, Title VII: Legislative History, 7 B.C. IND. \& COM. L. REv. 431 (1966). 
Mr. ERVIN. Under Title VII, an order can be entered ordering a man to pay back wages to a person who had never done a day's work for him. The amount of back wages may largely exceed the jurisdictional amount requiring a jury trial in common law cases under the Constitution. Title VII contains no requirement for a jury trial under any circumstances?

Mr. CASE. So far as the Act itself is concerned, there is no provision for jury trial. Of course, whether a jury trial would be required would depend upon the Supreme Court in developing further its decision of the day before yesterday in the Barnett case. A jury trial might be provided if the penalty were heavy enough.

Mr. ERVIN. No jury trial is provided.

Mr. CASE. No jury trial is provided under the terms of this section..$^{30}$

The weight of the evidence would appear to support the proposition that Congress did not intend to provide a right to jury trial in the enforcement litigation under Title VII.

\section{Constitutional. Right To Jury Trial}

Assuming that there is no jury trial right provided in the legislation itself, the more difficult constitutional question remains. As noted earlier, it was on constitutional grounds that the district court in Johnson v. Georgia Highway Express, Inc. upheld the defendant employer's demand for a jury trial, ${ }^{31}$ and it is the issue of constitutionality which the courts have found more difficult to resolve.

\section{A. The Test of History}

The constitutional basis of the right to jury trial in civil cases is the seventh amendment:

In suits at common law, where the value in controversy shall exceed twenty dollars, the right of trial by jury shall be preserved, and no fact tried by jury shall be otherwise reexamined in any court of the United States, than according to the rules of common law.

Because the seventh amendment sought to preserve an existing standard for determining the scope of the right to jury trial rather than to establish a new standard, the courts have held that the constitutional right

30 I10 Conc. REc. 7255 (1964). The "Barnett case" referred to by Senator Case is United States v. Barnett, 376 U.S. 681 (1964), which involves the right to jury trial in criminal contempt proceedings.

3147 F.R.D. 327, 331 (N.D. Ga. 1968). 
to jury trial in civil cases is to be determined by reference to the jury trial right as embodied in the English common law of 1791, the effective date of the amendment. ${ }^{32}$ It is accepted judicial doctrine that the constitutional right to jury trial was fixed at a particular point in time, and questions as to its scope are to be answered by the test of history ${ }^{33}$

In 1791 the determination whether a jury would sit in a civil suit was largely mechanical. Generally, actions brought in courts at law had issues of fact tried to a jury; suits brought in courts of equity were tried before a chancellor without a jury. In applying the historical test to a particular case, the modern court asks the deceptively simple question: In which court, law or equity, would the action have been tried had it been brought in 1791 ?

As Fleming James has demonstrated, ${ }^{34}$ however, the historical test has proven to be an unsatisfactory means of resolving the jury trial issue. The fundamental problem is that in 1791 the right to jury trial depended not upon the merits of having a jury in a particular case, but upon the court in which the action happened to have been filed. Nor did the litigant choose his court primarily upon consideration of the availability of jury trial; other factors such as discovery procedures, methods of introducing evidence, and available forms of relief influenced the choice of forum..$^{35}$ James concludes that "[a]t no time in history was the line dividing equity from law altogether-or even largely-the product of a rational choice between issues which were better suited to court or to jury trial." 36 The historical test thus forces the courts to decide the issue of the constitutional right to jury trial on the basis of historical criteria which were never intended to fulfill this purpose. Moreover, with the merger of law and equity, ${ }^{37}$ this is apparently the only purpose which the law-equity distinction still serves.

Even if the historical test is viewed as an appropriate concept for determining the right to jury trial, intelligent application of the test

32 See, e.g., Dimick v. Schiedt, 293 U.S. 474, 476 (1935); Baltimore \& Carolina Line, Inc. v. Redman, 295 U.S. 654,657 (1935).

33 See, e.g., 5 MOORE's Federal Practice of 38.11(2), at 108 (2d ed. 1968): "But what Congress in its discretion had thus given it could modify or take away, and hence the Seventh Amendment was adopted in 1791 to safeguard the common law right of jury trial. The Amendment is preservative in character and neither enlarges nor restricts the right of jury trial as it was known to the English common law at the time the Amendment was adopted." See also cases cited note 28 supra.

34 F. James, Givil Procedure 340-8 (1965).

$35 \mathrm{Id}$. at $344-5$.

$36 \mathrm{Id}$. at 344 .

37 See text at note 40 infra. 
is virtually impossible. The line between law and equity was not well defined even in 1791. Law courts frequently decided claims cognizable in equity courts and courts of equity were steadily increasing the scope of their jurisdiction. ${ }^{38}$ The result was "a very large overlap between law and equity." 39 In 1938 the division between law and equity was abandoned in the federal courts, and the two forms of action were merged. ${ }^{40}$ The historical test perpetuates the problems that merger was intended to eliminate by requiring the separation of issues within a single action on the basis of the discarded distinction between law and equity. Conversely, the merger compounded the problems of applying the historical test by removing what little identifiable distinction did still exist between the two categories. Finally, the creation of new statutory rights and remedies unknown at common law presents still another problem in applying the test of history. The historical test requires analogies between newly created actions and those existing in $1791^{41}$-analogies which are seldom accurate and which are drawn only for the purpose of categorizing the action as "legal" or "equitable."

These criticisms of the historical test demonstrate the need for a new approach to the problem of defining the constitutional right to jury trial. While the most rational solution may be the adoption of a constitutional amendment more explicit in its underlying purpose and more appropriate to the context of changing procedures, an attempt to reconstruct the criteria on which the right to jury trial should be based is beyond the scope of this comment. However, it is important to note that highly subjective questions of damages, which are often felt to be particularly appropriate for jury determination, are not present in Title VII cases. ${ }^{42}$ Back pay awards usually involve a definite amount for a definite period of time, and the total amount in controversy often can be stipulated by the parties. Most problems in determining the amount of a back pay award would be ones of computation rather than subjective evaluation. Nevertheless, because neither a con-

38 See, e.g., 1 W. Holdsworth, A History of ENGLish LAw 634-5 (7th ed. 1956).

30 F. James, Civil Procedure 342 (1965).

40 FED. R. Crv. P. 2.

41 See, e.g., Martin v. Detroit Marine Terminals, Inc. 189 F. Supp. 579, 581 (E.D. Mich. 1960); 5 Moore's Federal Practice of 38.11(7) (2d ed. 1968).

42 It has been suggested that tort remedies might be available for complainants discriminated against in violation of Title VII. Note, Tort Remedies for Employment Discrimination Under Title VII, 54 VA. L. REv. 491 (1968). If such remedies as exemplary damages and damages for mental suffering were available, the subjective difficulties of assessment would more clearly represent the type of problem that has traditionally been regarded as most appropriately left to a jury. In Allen v. Braswell Motor Freight Lines, supra note 19, the only case discovered which has been tried to a jury, the court did give an instruction on exemplary damages and damages for mental suffering. 
stitutional amendment nor a revolutionary reinterpretation of the seventh amendment by the Supreme Court is immediately foreseeable, ${ }^{43}$ any analysis of the right to jury trial under Title VII probably has to be made in terms of the existing case law-however unsatisfactory the basis of this case law may be conceptually.

\section{B. Judicial Precedent}

An examination of the judicial handling of the jury trial issue under similar remedial statutes which, like Title VII, involve both injunctive relief and monetary awards reveals that the courts have consistently denied the right to jury trial in such proceedings. In NLRB v. Jones \& Laughlin Steel Corp., ${ }^{44}$ the Supreme Court rejected the defendant's contention that it was deprived of its constitutional right to jury trial in an action seeking an injunction and back pay under section 10(c) of the National Labor Relations Act: ${ }^{45}$

The instant case is not a suit at common law or in the nature of such a suit. The proceeding is one unknown to the common law. It is a statutory proceeding. Reinstatement of the employee and payment for time lost are requirements imposed for violation of the statute and are remedies appropriate to its enforcement. The contention under the Seventh Amendment is without merit. ${ }^{46}$

A year earlier in Agwilines, Inc. $v . N L R B,{ }^{47}$ the Court of Appeals for the Fifth Circuit, in upholding the denial of jury trial right under the same Act, emphasized the public nature of the proceeding:

The proceeding is not, it cannot be made, a private one to enforce a private right. It is a public procedure, looking only to public ends .... Statutory provisions of this kind in the public interest are not considered as conferring common-law rights requiring trial by jury. They provide for public proceedings, equitable in their nature. They exert power to restore status disturbed in violation of statutory injunction similar to that exerted by a chancellor in issuing mandatory orders to restore status. ${ }^{48}$

43 One reason why a radical change in approach to the jury trial issue is not likely to occur is that opinions about the merits and functions of civil juries vary widely. See F. James, Civil Procedure 347, 378 n.3 (1965).

44301 U.S. 1 (1937).

4549 Stat. 454 (1935).

46301 U.S. at $48-9$.

4787 F.2d 146 (5th Cir. 1936).

48 Id. at 150 - I. 
Suits brought under section 17 of the Fair Labor Standards Act ${ }^{49}$ provide another example of a proceeding in which monetary awards combined with injunctive relief are available without a right to jury trial. In Wirtz $v$. Jones, ${ }^{50}$ a suit brought under this section, the court relied on the public purpose of the statute in rejecting defendant's seventh amendment argument:

... the purpose of the injunction to restrain the withholding of wages due is not to collect a debt owed by an employer to his employee but to correct a continuing offense against the public interest. It is true that as a result, money may pass from the pocket of the employer into the pocket of the employee or, if he is not available, then into the coffers of the United States Treasury, but that enforced payment, which must be made even if the employee or his representatives or heirs no longer exist to claim it, is simply a part of a reasonable and effective means which Congress, after trial and error, found it necessary to adopt to bring about general compliance with $\S 15(a)(2) \ldots$. The Seventh Amendment does not require Congress to blunt the most competent means of insuring general compliance with a key section of the Act by depriving the equity courts of a significant part of their inherent power..$^{51}$

Similar language can be found in the Supreme Court's denial of the right to jury trial under Section 205(a) of the Emergency Price Control Act of 1942.52

The public-private distinction which the courts have drawn in these cases is vulnerable to criticism on analytical grounds. Even if one accepts the proposition that an action intended primarily to vindicate a public right is sufficiently distinguishable from any "suit at common law" to fall outside the scope of the seventh amendment's jury trial guarantee, one is still left with the problem of distinguishing public and private actions. For example, a "private" action for treble damages under the Clayton Act, ${ }^{53}$ for which the courts have held that there is a constitutional right to jury trial, ${ }^{54}$ would appear to vindicate the leg-

4929 U.S.C. $\S 217$ (1964).

50 340 F.2d 901 (5th Cir. 1965).

51 Id. at 904-5.

5256 Stat. $\$ 33$ (1942). See Porter v. Warner Holding Co., 328 U.S. 395, 402 (1946).

6315 U.S.C. $\S 15$ (1964).

54 See, e.g., Fleitmann v. Welsbach Street Lighting Co., 240 U.S. 27,29 (1916) in which the Supreme Court established that there was a constitutional right to jury trial in antitrust actions for treble damages under the earlier Sherman Act. 
islatively determined public policy of fostering competition. Even plaintiffs in private tort actions may be characterized as protectors of the public interest who prompt society to adhere to generally accepted standards of reasonable behavior by pursuing their individual remedies. In short, individual relief and the public interest are not mutually exclusive categories:

When ... an effort is made to insist too absolutely on the current dogma that public and private right are insulated, noncommunicating chambers there is apt to be violence to the psychological and emotional props upon which wise judgment rests. ${ }^{55}$

Despite these analytical difficulties which weaken the force of any argument based on the public-private dichotomy, the question, which the courts will continue to pose, remains: Are proceedings under Title VII more closely analogous to those proceedings which have been deemed "public" and outside the scope of the seventh amendment's jury trial guarantee; or are such proceedings in the same class as the "private" sections of the above-mentioned statutes, ${ }^{56}$ which have been held to require jury trials?

Because the suits brought under the NLRA, FLSA, and EPGA discussed above were brought by government officials and agencies, the Title VII suit instituted by private individuals appears to be distinguishable. This distinction is reinforced by cases requiring jury trials in actions brought by private individuals under the sections of the FLSA and EPCA authorizing such suits. ${ }^{57}$ A closer examination of the statutes, however, discloses that such a distinction predicated on whether a private party or a public official initiates the action is more apparent than real.

First, the private actions requiring jury trial under the FLSA and EPCA do not, as do Title VII proceedings, involve injunctive relief; only monetary relief is provided. As has been noted, the actions brought by public officials or agencies under these statutes seek the same type of mixed injunctive and monetary relief as that sought by the individual complainant in a Title VII suit. In fact, the statutory language in the relief provision of the NLRA-an unquestionably "public" proceeding in which there is no right to jury trial-is almost identical to

55 Jaffe, The Public Right Dogma in Labor Board Cases, 59 HARv. L. REv. 720, 726 (1946).

58 See discussion following note 57 infra.

57 See, e.g., Olearchick v. American Steel Foundries, 73 F. Supp. 273 (W.D. Pa. 1947) (§ 16(b) of FLSA); Porter v. Warner Holding Co., 328 U.S. 395, 401-2 (1946) (§ 205(e) of EPCA). 
the relief provision for actions by individuals under Title VII.58 Second, the right to jury trial does not depend simply on whether a private individual or public official brings the action under these statutes, as the cases under the FLSA illustrate. While the courts have held that there is no jury trial right when the Secretary of Labor seeks an injunction and payment of back wages under section 17 of the FLSA, 59 and that there is a right to jury trial in actions brought by a private individual for money damages under section $16(\mathrm{~b}),{ }^{60}$ they have also held that there is a right to jury trial when the Secretary of Labor brings an action under section $16(c)$ for purely monetary relief. ${ }^{61}$ The requirement of jury trials under section $16(\mathrm{c})$ is consistent with the accepted doctrine that if the government brings a suit which is held to be one cognizable at common law, it is subject to the mandate of the seventh amendment. ${ }^{62}$

The distinction between actions by individuals under Title VII and private actions under the FLSA and EPCA is further illustrated by the discretionary nature of monetary relief under Title VII. As noted above, ${ }^{63}$ the language of the statute suggests that the court may grant or deny monetary relief at its discretion, and the courts have adopted that interpretation. ${ }^{64}$ Thus, even if an individual proves that he has been unlawfully discriminated against, and indeed that he has suffered financial injury, the court may deny him monetary relief. By contrast, under the private relief provisions of the FLSA and EPCA, once the plaintiff proves that he has been injured by unlawful labor practices or unlawful prices, he is entitled by law to receive monetary relief. ${ }^{65}$ This contrast both highlights the "equitable" nature of private Title

58 See text at note 26 supra.

59 Wirtz v. Jones, 340 F.2d 901 (5th Cir. 1965); Sullivan v. Wirtz, 359 F.2d 426 (5th Cir. 1966), cert. denied, 385 U.S. 852 (1966) (Justice Black dissenting).

60 Olearchick v. American Steel Foundries, 73 F. Supp. 273 (W.D. Pa. 1947).

01 Wirtz v. Turner, 380 F.2d 11 (7th Cir. 1964). See also Wirtz v. Jones, 340 F.2d 901, 904 (5th Cir. 1965).

62 See 5 MIOore's Federal Practice I 38.31[1] (2d ed. 1968) and cases cited therein.

63 Text at note 24 supra.

64 "As seen by the Act itself the right to recover any money judgment at all is" optional with the court." Culpepper v. Reynolds Metals Co., 296 F. Supp. at 1241. "The Court may, but is not required to, include in the relief afforded reinstatement or hiring of employees, with or without back pay." Madlock v. Sardis Luggage Co., 302 F. Supp. 866, 877 (1969). See also Bowe v. Colgate-Palmolive Co., 272 F. Supp. 332, 358 (S.D. Ind. 1967), rev'd on other grounds, $61 \mathrm{CCH}$ Lab. Cas. If 9326 (7th Cir. 1969).

65 "Any employer who violates the provisions of section 206 or section 207 of this title shall be liable to the employee or employees affected. . . " 29 U.S.C. § 216(b) (1964) (emphasis added). Section 205(e) of the EPCA provided the injured buyer with a right to bring an action for a specific amount of monetary damages for which the seller was liable if the price was found to have been unlawful. 
'VII relief and supports the conclusion that actions by individuals un:der Title VII are more closely analogous to actions by government officials under FLSA and EPCA than to private actions under those statutes. This conclusion is also supported by Jenkins $v$. United Gas Corp..${ }^{66}$ a Title VII case in which the plaintiff alleged that he had been denied a promotion because of his race. The defendant responded that the case was moot because the plaintiff had accepted a subsequent promotion. The court said that the public policy enforcement aspect of the suit had not been mooted: "The suit is . . . more than a private claim by the employee seeking the particular job which is at the bottom of the charge of unlawful discrimination filed with EEOC. When conciliation has failed . . that individual, often obscure, takes on the mantel [sic] of the sovereign." 67

The two "dominant"68 Supreme Court cases which have considered the constitutional right to jury trial are Beacon Theatres, Inc. v. Westover ${ }^{69}$ and Dairy Queen, Inc. v. Wood, ${ }^{70}$ both of which upheld seventh amendment jury trial claims. In Beacon Theatres the Court held that the counterclaimant in a declaratory judgment action brought in anticipation of a suit under the antitrust laws could not be deprived of his right to jury trial "merely because [the prospective defendant] took advantage of the availability of declaratory relief to sue [the petitioner] first." 71 The case involved the section of the Clayton Act which provides for a private remedy, ${ }^{72}$ and the Court pointed out that the legislators intended to provide for jury trial in such actions:

Since the right to trial by jury applies to treble damage suits under the anti-trust laws, and is, in fact, an essential part of the congressional plan ... the Sherman and Clayton Act issues on which Fox sought a declaration were essentially jury questions. $^{73}$

86400 F.2d 28 (5th Gir. 1968).

67 Id. at 32.

68 Culpepper v. Reynolds Metals Co., 296 F. Supp. 1232, 1240 (N.D. Ga. 1969).

69359 U.S. 500 (1959).

70369 U.S. 469 (1962).

71359 U.S. at 504. The extent to which the language of Beacon Theatres can be applied is somewhat uncertain. In Katchen v. Landy, 382 U.S. 323 (1966), a recent case involving the seventh amendment issue in bankruptcy proceedings, the Supreme Court ruled that the congressional intent "contemplating the prompt trial of a disputed claim without the intervention of a jury ..." was strong enough to satisfy denial of the right to jury trial "even though the results might be dispositive of the issues involved in a legal claim." Id. at $339-40$.

7215 U.S.C. $\$ 15$ (1964).

73359 U.S. at 504 (emphasis supplied). 
Nothing in Beacon Theatres suggests that there is a jury trial right under Title VII since that case deals only with attempts by potential defendants to avoid jury trials by originating the action in a "nonlegal" guise. Under Title VII trial by jury is not "an essential part of the congressional plan," nor is the action sufficiently like a common-law action to require a jury trial, regardless of which party originates the suit.

In Dairy Queen the Court upheld petitioner's demand for jury trial, even though the pleadings framed the damage claim as an "equitable accounting." Stating that "the constitutional right to trial by jury cannot be made to depend upon the choice of words used in the pleadings," 7 the Court held the controlling question to be whether there exists any "legal" claim cognizable at common law-regardless of whether that claim is characterized as "incidental" to an equitable claim. ${ }^{75}$ In sustaining petitioner's jury trial demand, the Court found that the claims at issue were directly analogous to traditional common-law actions:

As an action on a debt allegedly due under a contract, it would be difficult to conceive of an action of a more traditionally legal character. And as an action for damages based upon a charge of trademark infringement, it would be no less subject to cognizance by a court of law. ${ }^{76}$

Thus, the rationale of Dairy Queen does not require jury trials in Title VII actions: not only are Title VII actions readily distinguishable from actions of a "traditionally legal character" 77 which provided the

74369 U.S. at $477-8$.

75 Justice Black fails to distinguish between the terms "claim," "cause of action," and "issue" which he employs interchangeably in the Dairy Queen opinion. It appears, however, that his references are to the various separable "legal" and "equitable" claims such as breach of contract or trademark infringement which may be joined in a single pleading. For example, after stating in the text of the opinion that a jury trial right exists whether "the legal issues [are] presented as 'incidental' to the equitable issues or not," 369 U.S. at 473 , his footnote reference to that statement which presumably supports the textual statement includes the proposition that "[a]s long as any legal cause is involved, the jury rights it creates control." Id. at n.8.

76369 U.S. at 477 . As noted by the Court, an action for damages resulting from a trademark infringement could be brought at common law. See Trade-Mark Cases, 100 U.S. 82, 92 (1879). A trademark infringement action was thus cognizable both at law and in equity, and there is no question that the plaintiff desirous of trying his trademark infringement case before a jury could do so if he brought his case at law. "The right to adopt and use a symbol or a device to distinguish the goods or property made or sold by the person whose mark it is, to the exclusion of use by all other persons, has been long recognized by the common law and chancery courts of England and of this country ...."Id.

77369 U.S. at 477. 
basis for the Court's decision in Dairy Queen, but they are also most closely related to the public or equitable actions based on remedial statutes which have been held to be outside the scope of the seventh amendment's jury trial guarantee.

\section{Conclusion}

The language and legislative history of Title VII suggest that Congress did not intend to provide a right to jury trial in civil suits brought under the statute. Whether Title VII suits involving monetary awards fall within the constitutional guarantee of jury trial is a more difficult problem. The entire area of constitutional right to jury trial in civil actions is confusing and confused. Nevertheless, the relevant case law indicates that there is no such constitutional right in Title VII cases. Although the analytical bases for their resultwhether they be the legal-equitable or public-private distinctionare not entirely satisfactory, the accepted doctrines and line of precedent lead to a conclusion which is consistent both with the legislative intent to exclude jury trial and with the broad remedial purposes of Title VII. But further, it is submitted that in resolving the jury trial issue in statutory proceedings courts should not reject an apparent legislative choice to exclude jury trials simply on the basis of constitutional arguments which are subject to manipulation through the use of contrived historical comparisons. Rejections of the legislative choice should be made only for reasons which are self-evident and logically self-supporting. 